\title{
Т.Д. Маканбаев
}

\author{
Әл-Фараби атындавы Қазақ Ұлттық Университеті, тарих, археология және этнология \\ факультетінің 2-курс докторантьл, \\ Алматы к., Қазақстан \\ E-mail: talgat.makanbai@gmail.com
}

\author{
Г.А. Сексенбаева \\ m.в.д., доиент, әл-Фараби атындавы Қазақ ұлттық университетінің профессоры \\ Алматы к., Қазақстан \\ E-mail: seksenbaevaguzira@gmail.com
}

\section{ҚАЗАҚСТАНДАҒЫ АРХИВ САЛАСЫНЫҢ КЕЙБІР АСПЕКТІЛЕРІ Андатпа}

Жиырмасыншы ғасыр Қазақстан тарихында және оның құрамдас бөлігі ретінде жалпы отандық архив ісінің тарихында оқиғаларға ең қанық кезең болды. Олар мемлекеттік, саяси, қоғамдық, экономикалық және мәдени өмірдің барлық жағына түбегейлі түрде әсер етті. Соғыстар, революциялар, саяси құрылыстың ауысуы, КСРО қалпына келтірілуі және ыдырауы жиырмасыншы ғасыр осылай бастау алды және аяқталды.

Бұл мақала Қазақстандағы көп жылдық архив процесінің барысы мен жеке көріністерін түсіну талпынысы болып табылады. Отандық архив ісінің кеңестік кезеңінің барлық тарихы мемлекеттік саяси жүйесінің тарихымен, бір партиялық идеологияның монополиялық өктемдігімен, архив бөлігі болатын адамның рухани саласында әкімшілік қысыммен тығыз шырмалған.

Архив ісінің дамуының жаңа орамы КСРО ыдырағаннан кейін орын алды: архивтер жүйесі дербес болды. Тәуелсіз Қазақстан архив ісін демократияландыру үшін бірқатар архив реформаларын жүргізді. Аталған түрлендірулер нәтижесінде архивтерды басқарудың жаңа жүйесі қалыптастырылды. Архив ісі еліміздің мәдени мұрасының бөлігіне айналды.

Мақалада архивтің құрылуындағы басым бағыттарды анықтауға және отандық архив ісін жүргізудегі негізгі мәселелерге басты назар аударылады. Жеке архивтердің тарихтарына көп көңіл бөлінбейді, себебі оның жалпы фактографиялық бөлігі қазақстандық авторлардың монографияларында, оқу құралдарында және көптеген мақалаларында жеткілікті түрде толық көрсетілген.

Түйін сөздер: архивтер, архивтерді орталықтандыру, архивтерді басқару жүйесі, мемлекеттің саяси жүйесі, архив реформасы, архив заңнамасы.

\section{Т.Д. Маканбаев ${ }^{l}$}

Казахский национальный университет им. Аль-Фараби, докторант 2 курса факультета истории, археологии и этнологии,

2. Алматы, Казахстан

E-mail: talgat.makanbai@gmail.com

\section{Г.А. Сексенбаева}

д.и.н., доцент, профессор Казахского начионального университета им. аль-Фараби

2. Алматы, Казахстан

E-mail: seksenbaevaguzira@gmail.com 


\title{
НЕКОТОРЫЕ АСПЕКТЫ АРХИВНОЙ ОТРАСЛИ КАЗАХСТАНА
}

\section{Абстракт}

Двадцатый век в истории Казахстана в целом и в истории отечественного архивного дела как ее составной части оказался наиболее насыщенным событиями. Они коренным образом повлияли на все стороны государственной, политической, общественной, экономической и культурной жизни. Войны, революции, смены политического строя, восстановление и распад СССР - так началось и так закончилось двадцатое столетие.

Данная статья является попыткой осмыслить ход и отдельные аспекты многолетнего архивного процесса в Казахстане. Вся история отечественного архивного дела советского периода тесно переплетена с историей политической системы государства, с монопольным господством однопартийной идеологии, с административным нажимом в духовной сфере человека, частью которой являются архивы.

Новый виток развития архивного дела произошёл после распада СССР: система архивов стала самостоятельной. Независимый Казахстан провел ряд архивных реформ по демократизации архивного дела. В результате указанных преобразований была сформирована новая система управления архивами. Архивное дело становится частью культурного наследия страны.

Главный акцент в статье делается на выявление ведущих тенденций в архивном строительстве и узловых проблем в отечественном архивоведении. Меньше внимания уделяется истории отдельных архивов, поскольку в целом ее фактографическая часть достаточно полно отражена в монографиях, учебных пособиях и многочисленных статьях казахстанских авторов.

Ключевые слова: архивы, централизация архивов, система управления архивами, политическая система государства, архивная реформа, архивное законодательство.

\author{
Talgat Makanbaev ${ }^{l}$ \\ 2st year doctoral degree study Al-Farabi Kazakh National University \\ Almaty, Kazakhstan \\ E-mail:talgat.makanbai@gmail.com
}

Gulzira Seksenbayeva ${ }^{2}$

Associate professor, Doctor of historical sciences Al-Farabi Kazakh National University

Almaty, Kazakhstan

E-mail: seksenbaevaguzira@gmail.com

\section{SOME ASPECTS OF THE ARCHIVAL INDUSTRY OF KAZAKHSTAN}

\begin{abstract}
The twentieth century turned out to be the most eventful for the history of archiving, and for the history of Kazakhstan as a whole. This has profoundly affected all aspects of the state, political, social, economic and cultural life. Wars, revolutions, changes in the political system, the restoration and collapse of the USSR - this is how the twentieth century began and ended.

This article is an attempt to understand the course and certain feature of the long-term archival process in Kazakhstan. The entire history of archives of the Soviet period is closely intertwined with the history of the political system of the state. The history of archives is related to the monopoly rule of oneparty ideology, with administrative pressure in the spiritual sphere of man, including pressure over archives.

A new milestone in the development of archiving took place after the collapse of the USSR, so the archive system became independent. Independent Kazakhstan has carried out a number of reforms to
\end{abstract}


democratize archival activities. As a result of these changes, a new archive management system was formed. Archives become part of the country's cultural heritage.

The article focuses on identifying the leading trends in the formation of archives and key problems in the domestic archival science. Less attention is paid to the history of individual archives, since in general this is fully reflected in monographs, textbooks and numerous articles of Kazakhstani authors.

Keywords: archives, centralized archives, archive management system, political system of the country, archival reform, archival legislation.

\section{Kipicne}

Кеңес билігі орнағаннан кейін 1919 ж. 10 шілдеде РКФСР ХКК Декретімен әскериазаматтық басқару органының сипатына ие болған Қырғыз (Қазақ) өлкесін басқару бойынша Революциялық комитет ұйымдастырылды. Қырревком РКФСР құрамында астанасы Орынбор қ. Қырғыз (Қазақ) Автономиялы социалистік Кеңес республикасын қалыптастыру бойынша жұмыстарды бірден бастады. Автономиялы республика дәрежесі заңды түрде 1920 ж. 26 тамызда заңды түрде рәсімделді. Қазақстан Ресей Федерациясының құрамына кіргендіктен, өлкелік архив қорын құруға РКФСР архив ісінің Бас басқармасының өкілдері белсенді түрде қатысқан. Автономиялы республикаға арнайы комиссия заңнамалы және тәжірибелік салада архив құрылысының тәжірибесін тарату үшін жіберілді [Максаков, 1969, б. 57, 121-122]. РКФСР Орынбор губерниясы бойынша Бас архивтің бірінші әкілі Александр Петрович Михайлов құжаттарды тіркеу бойынша жұмысты бірден бастады. Сол уақыттардағы газеттерде өткен жылдардың құжаттарын мемлекеттік сақтауға жіберу қажеттілігі туралы архив ісі бойынша барлық декреттер басылған. Барлық үкіметтік және қоғамдық мекемелерге, жеке тұлғаларға қараусыз қалған архивтерді қорғау бойынша іс-шаралар қабылдау, қолдарындағы барлық баспа материалдарды: газеттерді, брошюраларды, үнпарақтарды және т.б., сондай-ақ жеке архивтерді сақтау және архивке беру туралы үндеулер жарияланды [ЦГА РК, ф. 544, оп. 1, д. 5, л. 2-3].

Ұзақ жылдар бойы кеңестік республикалардың бірі болған Қазақстанда архив саясаты ресейлік үлгі бойынша және соған ұқсатылып құрастырылды. Қазақстан және онымен бірге барлық мемлекеттік органдар жалпы кеңестік аппараттың бөлігі ретінде қарастырылды, және қандай да бір сұрақтың шешімі «жоғарыдан», Мәскеуден жүргізілді.

1930 жылдың желтоқсанында ҚАКСР Орталық архив басқару туралы Ереже бекітілді. Алайда, республиканың мемлекеттік архив қоры РКФСР ММҚ құрамына кірді. Оның барлық қызметі РКФСР Орталық архив басқармасының директиваларының негізінде құрылды. Құжаттардың құндылығын орнату, сақтау мерзімін анықтау, оларды пайдалану қатаң түрде РКФСР ОМБ рұқсатымен жүргізілді. 1936 ж. конституция Қазақстанның архив органының қызметіне айтарлықтай өзгерістер енгізген жоқ. Республиканың РКФСР құрамынан шыққанына қарамастан, барлық архив қызметі КСРО, РКФСР және ҚазКСР үшін ортақ бірыңғай архив заңнамасының негізінде болды және жұмыс істеді. Қазақстан архивтерінің осындай дәрежесі 1991 жылы КСРО ыдырағанға дейін сақталды.

Мақсаты. Мақалада 1918-1991 жылдар аралығындағы Қазақстандағы архив органдарының қызметі сонымен қатар заманауи кезеңдегі архивтар мен құзіреттілігін архив құжаттарын кеңінен ғылыми айналымға тарта отырып зерттеу, ғылыми негіздеу және объективті түрде ашып көрсету басты мақсаты ретінде қойылды. Осыған сәйкес мынадай міндеттерді шешу назарға алынды:

- архив мекемелерінің қалыптасу тарихы мен кезеңдері анықтау;

- кеңестік кезеңдегі архив ісі

- заманауи кезеңдегі архивтер

Материалдар мен әдістер: Аталған Қазақстандағы архив саласының кейбір аспектілері атты макқалада нақтылық принциптері басшылыққа алынады. Төл деректерге басымдылық беру, жалпығылыми және жалпытарихи әдістер қолданылып, тарихи үдерістерді сипаттау және тақырыпқа қатысты әртүрлі фактілерді жан-жақты талдап, тарихи шынайылыққа жақындау үшін объективтілік және тарихилық, сондай-ақ, жүйелілік қағидалары басшылықта ұсталды.

\section{Нәтижелерді талқылау.}

Тәуелсіз алғаннан кейінгі уақытта тарихшылар тарапынан және де архив саласы бойынша еңбек жазып, қызмет жасап жүрген азаматтар тарапынан сонау кеңестік дәуірдегі архив

органдарының қызметіне көңіл бөліне бастады. Әрине Кеңес тарихнамасында да бұл мәселе қарастырылды, атап айтар болсақ. 
Белгілі ғалым В.В. Максаков өзінің "Архивное дело в первые годы Советской власти" атты зерттеуінде 1918 жылы қабылданған "лениндік декреттің" РСФСР Халық Комиссарлар Кеңесі мүшелерінің арасында талқылануға салынғандығы туралы айта келіп, бұл декреттің ұйымдастырушысы тарихшы, Халықатқару комиссарының орынбасары М.Н. Покровский болғанын жазады.

С.Н. Валк "О тексте декретов Октябрьской Социалистической революции и необходимости научного их издания" деген мақаласында "лениндік декрет" түпнұсқасымен оның жарияланған текстінің арасындағы айырмашылыққа әкелді дейді. Мысалы, декреттің үшінші пунктінің түпнұсқасында: "...күнделікті қызметке қажетті істер, осы ведомствоның қарауында қалады, бірақ архив ісінің жоғарғы басқармасының қарамағына кіріп өз қызметін жалғастырады", жарияланған тексте - "...осы ведомство бөлімінде қалып, архив ісінің жоғарғы қарамағына өтпейді" делінген. Мұндай айырмашылықтар қарама-қайшы талқылауға негіз болды: түпнұсқада істер ведомстволық уақытша қолдануға қалтырылады, жарияланған тексте - істер Мемлекеттік архив қорына мүлдем түспейді. Бұндай қарама-қайшылыққа алғаш рет 1939 жылы С.Н.Валк назар аударып осының негізінде мақала жариялады.

В. Введенский "Архивное строительство в Казахстане" деген зерттеуінде 1921 жылы қаражаттың жетіспеуі мен аштық жергілікті жерлердегі архив ісінің ұйымдастырылуына кері әсерін тигізді дейді, архив құжаттары алып- сату көзіне айналды және көптеген орталық мекемелердің архивтары табиғат апаттарынан жапа шеккендігі туралы айтады.

Архив ісінің маманы, тарихшы И.Л. Маяковский революцияға дейінгі бай-помещниктердің жеке иеліктерінің қорларында мұражайлар мен кітапханалар жене банк сейфтарында сақталуға берілген тарихи - әдеби материалдардың мәселесі таласқа түскендігіне "архив, кітапхана, мұражай" деген мақала жариялады.

М.Ф. Петровская "Состав государственного архивного фонда Союза ССР и комплектование государственных архивов документальными материалами" атты зерттеуінде учаскелік сайлаушылар комиссиясының сайлаушылар бюллетені, дауыс беру хаттамалары кеңестердің атқару комитеттерінде сақталатын болды, бұдан кейін бұл құжаттық материалдар Қазақ ССР Ішкі Істер Министрлігінің қарамагына сақтауға жіберілетіндігі туралы айтады.

Сондай - ақ тәуелсіз Қазақстан жағдайында архив ісінің маманы М.С.Хасанаев өзініңарнайы зерттеуінде "Лениндік деген ғылыми айналымға енген 1918 жылғы декрет оның міндеттеріне әртурлі тусінік берді. "Орталықтандыру" түсінігін құнды құжаттарды сақтап қалу мақсатында деп емес, керісінше "басқаруды орталықтандыру" деп қабылдады дейді.

Ахмет А. «Қазақсатндағы архив ісінің тарихы (1918-1991жж.)»атты моногорафиясында Қазақстандағы архив ісіні қалыптасу тарихы кеңінен

қарастырылды деп жазылған, мен зерттеу жүргізіп отырған тақырып архив органдарының қызметі жайлы болмақ, бұл мәселе жоғарыда айтылған еңбектің 2 тарауы 1 тармақшасында айтылады бірақ бұл мәліметтер әлі де болса толықтыруларды сонымен қатар өіндік тұжырымдамаларды қажет етеді.

Жоғарыда айтылғандарды қорыта келе, мынадай тұжырымға келдім. Қазақстанда Архив бас басқармасының қызметі мен басқару жүйесі отандық архивтану ғылымында арнайы зерттелмеген. Сондықтан да архивтану ғылымында бұл мәселенің тереңірек зерттеле түсуі қажеттігі көрінеді .

Зерттеу нәтижесі:Кеңестік кезендегі архив ісі

Революциядан кейінгі кезеңде Қазақстандық архив ісі жеті онжылдықтан астам уақыт бойы кеңестік режимнің болған кезінде РФКСР ХКК өкілі В.И.Ленин қол қойған 1918 ж. 1 маусымдағы «Архив ісін қайта ұйымдастыру және орталықтандыру» декретіне сәйкес құрастырылды. Декрет жаңа кеңестік мемлекетте архив ісі реформасын жүзеге асыру үшін заңды негіз болды. Декрет идеясы архив ісін радикал қайта ұйымдастыру мен орталықтандыру бойынша бірінші тәжірибелік іс-шаралардың негізіне қаланды. Ол жеткілікті жалпы түрде елдегі архив ісінің жаңа ұйымының мағынасын көрсететін қысқаша бағдарламалық тезистерден тұратын декларация түріне ие болды.

Кеңестік мемлекетте архив саласының ары қарай жұмыс істеуі үшін осы құжаттың мағынасы мен ролі Патриция Гримстед Кеннедидің «Lenin's Archival Decree of 1918: The Bolshevik Legacy for Soviet Archival Theory and Practice» мақаласында жеткілікті түрде мазмұндалған [Grimsted P.K., American Archivist, 1982]. Патриция Гримстед Кеннедидің кеңестік архив ісінің белсенді, қызығушылық танытқан зерттеуші екендігін айта кету керек. Негізінен оның зерттеулері 
Ресейдің мемлекеттік архивтеріне қатысты мәселелерді қарастырады [Grimsted P.К., American Archivist, 1971,1973, 1989,1991].

Большевиктік билік архивтерді өзінің бақылауына алу бойынша жұмыстарды бірден бастаған. Бұл ең алдымен ірі архив қоймаларын құрудан көрінді. Орталықтандыру идеясының мағынасы (БММҚ - Бірыңғай мемлекеттік архив қоры) жалпы мемлекеттік көлемде орталықтандырылған архив жүйесін қалыптастырудан тұрады.

Қазақстанда архивтерді ерекше басқару қалыптасқанға дейін, декретті жүзеге асыруды құзыреттіліктері кең Орталықтардың құзыретті комиссарлары іске асырған. Осы жұмыстарға негізінен ең алдымен архив қызметінің басқару көріністерін шешкен коммунисттер қатыстырылды.

1922 ж. 24 қаңтарында республиканың Халық ағарту комиссариатының коллегиясымен Қазақ АКСР Орталық өлкелік архиві туралы бірінші ресми ереже бекітілді [Архивное строительство..., 1980, б.26-27]. Архив Қазақстан аумағында бас қойма дәрежесін алды. Архив мемлекеттік мекемелердің, сонымен бірге қоғамдық ұйымдар мен жеке тұлғалардың ғылымитарихи маңызы бар құнды және маңызды құжаттарын талқылау мен ретке келтірумен айналысты. Архив материалының сипаты бойынша өлкелік архив бірнеше секцияларға бөлінді: революция архиві, революцияға дейінгі құжаттар секциясы, ғылыми-анықтамалық кітапхана.

1925 жылдың 3 ақпанында Орталық архив коллегиясы жаңа «РКФСР ББМҚ ұйымдастыру туралы Ережені» бекітті. Құжат ББМҚ «мемлкетке тиесілі және РКФСР Орталық архивінің іс жүргізуіндегі ресми және жеке қолдағы барлық архив материалдарының жиынтығы» ретінде анықтады. Осылайша, барлық құжаттардың қай жерден шыққандығына, меншігіне және мазмұнына тәуелсіз оларды толық мемлекеттендіру бойынша негіздер заң жүзінде қалыптасты [Сборник руководящих материалов, 1961. б. 109-111].

Осы «Ереже» революциядан кейінгі кезеңнің архив қорын ұйымдастырудағы жаңа кезеңді ашты. Онда барлық материалдарды уақыт бойынша революцияға дейінгі кезеңге (тарихи архивтер) және революциядан кейінгі кезеңге (Қазан революциясының архивтері) бөлудің анық қағидасы орнатылды. Және соңында БММҚ барлық архив материалдары орталықтағы материалдар (яғни жоғарғы және орталық мекемелердің қорларының, сонымен бірге қоғамдық РКФСр көлемінде жұмым істейтін кәсіби, ұжымдық және басқа ұйымдардың) және жергілікті материалдар (яғни жергілікті мекемелердің, ұйымдардың және кәсіпорындардың материалдары) болып бөлінді.

Орталық ведомстволардың құжаттары және тарихи-революциялық материалдардың белгілі бір санаты басымдылыққа ие болды. Сондай ақ жеке архивтердің және қатардағы, біртуар емес тұлғалардан жиналған құжаттарына және «төменгі деңгейдегі» жергілікті архивтерге және т.с.с. назар аударылмады. Қорлардың құрамы өте қатаң түрде регламенттелді.

Одан да қатаң іс-шаралар «кеңес билігінің жауларына» қатысты қолданылды. РФКСР ХКК 1923 ж. 2 тамызындағы декретіне сәйкес осындай материалдардың барлығы БММҚ саяси секцияларына жіберілуі керек болған. Кейіннен жергілікті деңгейде ол ООК және ҚАКСР ХКК 1928 ж. 8 қыркүйектегі «Қазақ орталық архивіне тарихи-революциялық қызығушылыққа ие баспа және көрнекілік материалдарды, фотосуреттер мен кинофильмдердің негативтерін, сондай ақ бұрынғы хан, сұлтандардың, белсенді қайраткерлердің және Алаш Орданың бұрынғы үкіметінің жақтастарының және басқа «архив материалдарын» өткізу туралы» қаулысымен толықтырылды [Архивное строительство..., 1980, б. 60-64].

Жалпы «Ереже» архив ісін орталықтандыру қағидаларын бекітуге бағытталған. Ол барлық архив органдарын бірыңғай жалпы ресейлік органға - РКФСР Орталық архив басқармасына бағындыру ретінде түсінілді. Оның қарамағында құжаттардың құндылығын сараптау үшін құрамына партиялық және кеңестік органдардың өкілдері қосылған сенімдеу комиссиялары құрылды. Олар архив қызметкерлеріне қарағанда көп құзыреттіліктерге ие болды.

Сонымен қатар, ведомстволарға өздерінің материалдарын өздігімен құпиялылығын тексеру және осылайша еркін түрде оларға тұтынушылардың қолжетімділігін шектеу құқығы берілді. Анықтамалар, үзінді көшірмелер және көшірмелер жеке және мүлік құқықтарына қатысты сұрақтар бойынша және мемлекеттік немесе қоғамдық ұйымдарға ұсыну үшін ғана беріледі.

Негізінен «архив мекемелерінің бірінші кезекті міндеті» «архив қорларын реттеу міндеті» болды, ал оларды пайдалану мәселесі екінші орынға қойылды. ОМБ 1936 ж. 29 қарашадағы директивасында барлық кеңестік, республикалық, өлкелік және облыстық архив мекемелерімен құжаттарды талдауға, сипаттауға және тексеруге архив мекемелерінің жұмысшыларының барлық күші тағайындалды [Архивное строительство..., 1980, б. 109-110]. 
1938 ж. бастап заңды архив органдар толықтай тоталитарлық басқару құрылымына біріктірілді, ол архивтерді Ішкі істердің халық комиссариатының (IIXК) жүргізуіне беруде көрінді. 1938 ж. барлық архив жүйесін IIXK (1946 ж. бастап - Ішкі істер министрлігі (IIM)) алуы архивтерді жаппай саясаттандыру және мемлекеттендіру курсының логикалық аяқталуы болып табылды.

Архив ісін жаппай барлық жерде саясаттандыру олардың қоғамды басқарудың командаәкімшілік, ведомстволық басқару жүйесіне біртіндеп біріктірілуіне, одан кейін құрылған режиммен толықтай жұтылуына алып келді.

Екінші дүниежүзілік соғыс аяқталғаннан кейін архив материалдарын пайдалану үлкен көлемге ие бола бастады. Архивтердің құрамында ғылыми-баспа бөлімдері құрылады. Ғылымибаспа бөлімінің қызметіне архив құжаттарының барлық жинақтарына жаппай цензураны жүзеге асыру, сондай ақ авторларды, редакторларды және рецензенттерді іріктеу, қорытындыларды дайындау және елдегі барлық баспаларда архив жарияланымдарын жазуға және басып шығаруға дайындықты толық бақылау кірді. Кеңес республикаларының архив қызметтерінің барлық бастықтарына 1959 ж. 31 тамыздағы архив анықтамалықтарын құрастыру тәртібін қайта қарастыру туралы жабық хатта ішкі және сыртқы саясат бойынша және экономика бойынша материалдардың мазмұнын ақталмаған кеңінен ашу туралы көрсетілген ...».

КСРО ІІМ ММБ нұсқауы бойынша архивтердің жөнсілтерлері «Кеңес Одағының қызығушылықтарына қарсы пайдаланылуы мүмкін» құжаттардың аннотацияларына қосылмауы керек. Ғылыми-анықтамалық аппаратты жасау бойынша барлық жұмыс арнайы құрылған комиссияның қатаң бақылауына алынды.

ММБ басқа бөлімдерінің жұмысы туралы (ұйымдастырушылық-инспекторлық; архив қорларын жинақтау, сараптама және тіркеу; ғылыми-әдістемелік) архившілер кез келген деңгейдегі маманның әр қадамын регламенттеуге бағытталған барлық мүмкін болатын нормативті актілердің тұрақты түрде өсетін ағыны бойынша пікір алды.

Онжылдықтар барысында архившілердің ғылыми дербестігінің қалдықтарын жоюда, олардың өлкетану ұйымдарымен және шығармашылық ойлайтын тарихшылармен байланысын үзуде және соңында олардың партиялық - мемлекеттік диктатураға бағындырудың қатаң жүйесін орнатуда көрінген архивтерді өзіндік «милитарландыру» жүрді.

КСР Одағының және КСР орталық мемлекеттік архивтері торабының Мемлекеттік архив қоры туралы 1958 ж. 13 тамыздағы жаңа Ережесі қорлардың қажеттілігінің негізгі қағидасын растағанымен, бірақ елдегі архив мекемелерінің жүйесінде басымдылық жағдайды пайдаланған ведомстволардың архив дәрежесін жойған жоқ (кеңес республикаларының ҒА, КСРО IIM, КСРО Геология министрлігінің жалпы кеңестік геология қоры, Гидрометеорологиялық құжаттардың мемлекеттік қоры және тағы кейбір басқалары. Тізімде КОКП ОК, ІІМ, КСРО ҚМ және басқаларының архив қорлары аталмаған) (Советские архивы, 1978, № 3, б.21).

Жеке ведомстволармен құжаттарды тұрақты сақтауға құқық заңды түрде бекітілді және ол белгілі бір құрылымдардың архивтеріне қолжетімділікті шектеді. 1958 ж. ММҚ туралы Ережеде арнайы қорлар туралы айтылмаған («ерекше», «құпия» архивтер және жеке ведомстволардың заңды дербес архивтері), алайда олар тәжірибеде болған. ММҚ туралы жаңа Ережеде (1980) «Жалпы ережелер» концептуалды бөлімінде мемлекеттік архивтермен бірге тұрақты мемлекеттік сақтау орны «салалық ведомстволық қорлар және басқа ведомстволық архивтер» аталады [Архивное строительство..., 1980, б. 208].

КСРО МК 1960 ж. 13 қаңтардағы Қаулысымен ІІМ ММБ КСРО Министрлер Кеңесіндегі Бас архивке түрлендірілді [ЦГА КазССР, ф.544, оп.1, д.1836, л.43].

IIXК-IIM органдары жүйесінен архивтердің шығуы архившілердің жұмысында қандай да бір түбегейлі өзгерістерге алып келген жоқ. Енді ММБ министрліктердің ағымдағы іс жүргізуі мен КСРО ведомстваларының құжаттық бөлігінің қойылымын ғылыми-әдістемелік басқару қызметтері бекітіледі. Осылайша, Қазақ КСР Министрлер Кеңесінің 1964 ж. 6 қаңтардағы қаулысында елдегі іс жүргізудің қараусыз жағдайы, «еңбекшілерді коммунисттік тәрбиелеу және коммунисттік құрылыс мәселелерін шешу үшін» архив қорларын пайдаланудың күрделі кемшіліктері туралы көрсетілді [Архивное строительство..., 1980, б. 164-166].

Енді архивтер мен архившілер партиялық-бюрократиялық аппараттың қуатты және тармақталған құрылымының тікелей бақылауында болды. КОКП ОК архивтерді ең алдымен өзінің агитациялық-жарнамалау арсеналының бөлігі ретінде қарастырды. 
Министрлер Кеңесі архившілерді іс жүргізуді ұйымдастыру бойынша арнайы мамандарға айналдыру үшін барлығын істеді және архив ісінің кәсіби мамандарының қызмет саласын тек басқарма, ведомствалық саласымен шектеді.

Талдаулар көрсеткендей, тоталитаризм аясында жеке тағдыры жоқ. Шешімдер жеке әлеуметтік феноменнің ішкі өздік даму заңдарын, сондай ақ оның айрықшылығын, рухани мағынасын, мәдени көріністерін және т.б. ескермейтін ішкі органдармен қабылданады және мәжбүрленеді. 90-шы жылдардың басында архивтер мен архившілер тура осындай жағдайда болды.

Архив ортасы құрылған саяси жүйенің бөлігі бола отырып тоталитаорлы мемлекетте қолданылатын нормалар мен құндылықтарда жұмыс істей алмады. Қоғам тіршілігінің басқа салалары сияқты ол да саясаттандырылды, және архивтердің қолжетімділігі және ашықтылығы сияқты мәселелер идеологиялық дұрыстылыққа байланысты олар пайда болған сәттен бастап өзекті болып қалды. Осылайша, 20-шы жылдары қызығушылық танытқан ақпаратты алуда жеке тұлғалардың құқықтарын шектейтін ережелер қабылданды: оларға жеке құқықтарына қатысты анықтамалар ғана берілді. Сол кезде зерттеушілер толық мәтіндер мен жеке құжаттарды архив органдарының ерекше рұқсатынсыз жариялау құқығынан айырылды, барлық үзінді көшірмелердің барлығяын міндетті қарау талаптары енгізілді. Сонда қабылданған архив құжаттарын пайдалануға қатысты тыйым салу іс-шаралары Қазақстан архивтерінде сақталған көптеген ақпараттың барлығына пайдаланушылардың қолжетімділігінен ұзақ жылдарға айырды. Идеологиялық себептер бойынша бүтін құжаттық кешендерге, ресми бекітілген сызбалар бойынша архив көздерінің жарияланымдарына қолжетімділікті шектеу жүргізіліп жатқан процестерді бейтарап зерттеудің болмауына және тарихты түсіну мен тануға біржақты тәсілдің қалыптасуына алып келді.

Архивтер тарихын тек «қара бояулармен» көруге болмайды. Кеңестік мемлекеттің бірінші және келесі әрекеттері жасалған уақытына тәуелсіз құжаттық байлықты сақтауға бағытталды. Архив органдарының санкцияларынсыз архив істерін сату және жоюға тыйым салынды, мекемелермен құжаттарды беру тәртібі бекітілді, сақтауға түскен ақпарат көздерімен кәсіби негізделген жұмыстар басталды.

Саяси және идеологиялық пайдалылыққа байланысты кеңестік мемлекет құрылған алғашқы жылдардан бастап архивтердің міндетті түрде болуы керектігін мойындады. 1918 жылдың 1 маусымында декреттің шығуына байланысты архив ісі мемлекеттік деңгейде дербес құрылым ретінде танылды. Мақсатты, орталықтандырылған бюджет архив қоймаларын ұйымдастыруды және дамытуды, оларды техникалық жабдықтауды, біліктілігі жоғары кадрларды дайындауды дұрыс жолға келтіруге мүмкіндік берді. Архивтердің құрылған жүйесі ең алдымен жүз жылдықта жинақталған құжаттарды сақтауда өзінің тиімділігін көрсетті және архив қоймасына тарихи көздердің жүйелі түрде келуін, сақталатын архив құжаттарының пайдаланылуын қамтамасыз етті. Саяси себептер, идеологиялық мақсаттар құжаттамалық кешендердің сақталуына өз ізін қалдырғанымен, қазіргі сәтте алдыңғы кезеңдегі тарихтың берік және көп жақты архив-көзді базасына ие екендігі анық болып табылады.

Нормативті-әдістемелік әзірлемелермен нығайтылған ұйымдастырушылық шешімдер жиынтығының арқасында архив ісін қалдық қаржыландыру қағидасының тұрақты әрекет ету және осы жүйенің кейде түбегейлі қайта құрылу жағдайында архивтер өздерінің негізгі қызметтерін жүзеге асыра алды - тарихи көздерді жинақтау, сақтау және пайдалану. Сондай ақ архивтер құжатты басқару идеясын жүзеге асыра алды, оның нәтижесінде жалпы мемлекеттік көлемде құжаттар ағынын ұйымдастыру мен құжаттандырудың бірыңғай негізі құрылды.

Қазіргі күнгі көзқарас бойынша біз архив жүйесіне тән кемшіліктерді көреміз. Тоталитарлы мемлекет құрылымдарының бірі бола отырып, ол осы мемлекеттің қызығушылықтарынан тыс қызмет ете алмады. Архив ісінің саясаттандырылған және идеологияландырылған бөлігі архивтердің барлығы ғылыми-ақпараттық әрекеті, әсіресе құжаттарды сипаттау, пайдалану, жариялау әдістемесінде, ғылыми-анықтамалық аппаратты жасауда анық көрінген әрекеттері болды. Архивтің жариялылығының, ашықтылығының демократиялық қағидалары бұзылды, оның салдары архивтерге қолжетімділікті шектеу болды.

Сонымен бірге идеологиялық қысымға қарамастан, архив ісінің көптеген бағыттары сәтті дамыды және архив әдістемелерінің жеткілікті түрде тиімді құралдарын жасады. Осылай, кеңестік архив жүргізудің талассыз жетістігі қоғамның құжаттық мұрасын толықтыру үшін құнды құжаттарды іріктеу теориясы болып табылады, ал мемлекеттік қоймалардың құжаттары бойынша іздеу құралдарының жүйесі әлі күнге дейін ақпаратты тиімді іздеуді қамтамасыз етеді. 
Идеологиялық қалыпты қоспағанда архив процестерін реттейтін нормативті-әдістемелік құралдар жүйесі жалпы кәсіби көрсеткіштерге жауап береді. Ол уақыт бойынша тексеруден өтті және қазіргі уақытқа дейін архив тәжірибесінде кеңінен пайдаланылады.

Осылайша, қызметінде қолданыстағы саяси жүйенің басқару қағидалары мен механизмдері көрініс тапқан архивтің құрылым ретіндегі әрекеті аяқталды.

Заманауи кезеңдегі архивтер

Елде болған мемлекеттік-құқықтық және әлеуметтік-саяси түрленулер архив ісін ұйымдастыру қағидаларына және архив мекемелерінің жұмысының негізіне айтарлықтай әсер етті. Кеңестік архив саласымен сабақтастығын сақтай отырып жаңа архив ісін жүргізу бірқатар жаңа, одан түбегейлі маңызды ерекшеліктерге ие болды.

Саяси, экономикалық және әлеуметтік-мәдени өзгерістердің әсерімен мемлекеттік архив қызметінің мазмұнының түрі өзгереді, оның ролі мен қызметінің түсінігі түбегейлі жаңартылады.

Тиімді жұмыс істеген архивтердің орталықтанған жүйесінің бірқатар ұстанымдары қоғаммен құрылған тарихи көздердің сақталуын бақылауды жүзеге асырумен және архивтерді осындай көздермен мақсатты түрде жинақтауды ұйымдастырумен құрылады. Алдыңғы кезеңнің архив ісіне деген үйлесімді және бүтін жүйесін қамтамасыз еткен архившілерінің теориялық зерттеулері, әдістемелік және методикалық жұмыстары бүгінгі күнде де өзінің өзектілігін сақтайды.

Өткен жүзжылдықтың 90-шы жылдарының басында қабылданған жаңа саяси негізі және экономикалық қағидалары архив ісінің қызмет етуіне тікелей түрде әсер етті. Бұл сала 1998 жылдың соңына дейін кеңестік кезеңде қалыптасқан заңнамалық база негізінде жұмыс істеді. 90шы жылдардың басында Қазақстанның үкіметімен коммунисттік және жастар ұйымдарының архив кеңесіне, архив ақпаратының құпиясын ашуға, архив істерінің жеке санаттарына қолжетімділікті ашуға қатысты бірқатар қаулылар қабылданғанымен, оларды өзгерген жағдайдағы архив саласын реттейтін әрекет ретінде анықтауға болмайды.

Жаңа заңнамалық базаның ұзақ уақыт бойы болмауы архив саласының қызмет етуінің көптеген қиындықтарына алып келді. Бұл ең алдымен қаржыландыруда, материалды-техникалық базада, осы салада білікті мамандардың жеткілікті мөлшерде болмауында көрінді.

1991-1998 жылдардағы Қазақстанның архив ісінің дамуы туралы аналитикалық шолуда осы кезеңдегі ҚР архив саласын қаржыландырудың өте төмен болғандығы туралы қорытынды алынады. Республикада архив қоймаларының құрылысы мен жөндеу жұмыстары жүргізілмеген, ал материалды-техникалық жабдықтау өте төмен деңгейде болды. Құжаттарды сақтаудың: өртке қарсы, температура-ылғалды, санитарлы-гигиеналық, жарық сияқты нормативтік параметрлері ғана жартылай орындалған және құжаттардың сақталуына үнемі қатер тудырып отырды [http://archives.ru/documents/methodics/review-archival-delo-sng.shtml].

Бұрынғы экономикалық қатынастарды бұзу жағдайында мемлекет тарапынан қаржылық және техникалық қолдау өте төмен болғаны соншалықты, архивтер өткенді шолу құжаттамасының сақталуын қамтамасыз ететін архив жұмыстарының міндетті кешенін әрең жүргізуге тура келді. Техникалық мүмкіндіктер архивтерге сақталатын құжаттардың сақталуы және пайдаланылуы бойынша жұмыстарды тиімді жүргізуге мүмкіндік бермеді. Архивтердің жабдықтары мен техникасы сапалық және материалды ескірген.

Тиімді басқаруды ұйымдастырудағы қиындықтар білікті кадрлық құрамының жеткіліксіз мөлшерінен, қызметкерлер санының қысқаруынан және еңбекақының төмен болуына байланысты жұмыстан кету пайызының жоғары болуынан туындаған.

Осы кезеңде қысқаруы 29,5 \% құраған архивтерді жинақтау процесі күрделі болып қалды. Архивтерді толыққанды жинақтауға әсер ететін факторлардың арасында мекемелер мен ұйымдарды жою, тарату немесе олардың меншік түрін ауыстыру ғана емес, сонымен бірге архив қорларын толықтырудың құқықтық негіздерінің, жинақтау стратегиясының болмауы да көрсетіледі.

Жаңа саяси және экономикалық жағдайлар және қоғамды ақпараттандыру процесі Қазақстан архивтерінің жұмыстарына елеулі түзетулер енгізді. Архивтер халықтың материалдық және рухани өмірін көрсететін және елдің тарихи-мәдени мұрасының ажырамас бөлігі болып табылатын құнды құжаттаманың сақтаушысы ретінде өзінің дәрежесін сақтап қалды. Архивтердің қызметтері тарихи бөлікті сақтаумен шектелген жоқ. Олар сонымен бірге ведомстволық сақтау мерзімі аяқталғаннан кейін жинақтаудың негізгі көздерімен құжаттаманы жүйелі және міндетті түрде беру есебінен толықтырылып отырған өзекті бөлімді қалыптастыруды жалғастырды. 
Архив құжаттамасымен негізгі жұмыстардың әдістемесіндегі бұрынғы дәстүрлер және орындау технологиялары да сақталды. Сонымен бірге жаңа ақпараттық технологияларды енгізу архив көздерімен жұмыстың көптеген шараларына әсерін тигізді. Дәстүрлі жинақтау әдістемесінен ауытқу, архивтің өткенді шолу базасын сақтау және пайдалану саласына инновациялық технологияларды енгізу архивтер қызметіне айтарлықтай өзгерістерді енгізді.

Қоғамда әр түрлі мемлекеттік емес құрылымдардың пайда болуымен байланысты архив өз қызметінде күрделі қиындықтарға тап болды. Құжаттармен жұмысты нормативті-құқықтық қамтамасыз етудің ұзақ уақыт болмауы қоғам үшін құнды көзлермен жинақтауға жағымсыз әсер етті.

Түбегейлі маңызды ережелер бекітілген Қазақстан Республикасының «Ұлттық архив қоры және архивтер туралы» Заңы 1998 жылдың желтоқсанында ғана пайда болды [https://zakon.uchet.kz/rus/docs/Z980000326].

Архив заңнамасы әр түрлі меншік түрімен ведомстволық архивтердің жағдайын, жүргізілуін және сақталуын мемлекеттік бақылау қағидасын ұстанады. Сондай ақ архивтердің сақталуына жауапкершілік архив органдарының тарапынан міндетті бақылаумен мекеменің өзіне немесе олардың иесіне жүктеледі. Архив өз тарапынан мекемелерге ғылыми-әдістемелік, анықтамалық, ақпараттық көмек көрсету керек.

Архивтер туралы заңмен:

- архив ісінде және құжат айналымында бірыңғай мемлекетті саясатты қамтамасыз ету;

- Ұлттық архив қорын (ҰМҚ) және Құжаттардың көшірмелерінің мемлекеттік сақтандыру қорын қалыптастыру және олардың қызмет етуі;

- ҰМҚ құжаттарын орталықтандырылған мемлекеттік тіркеуді қамтамсыз ету;

- ҚР тарихы бойынша шет елдегі архив құжаттарын жинау және қайтару;

- архив ісі мен құжаттарды жүргізуді мемлекеттік дамыту бағдарламаларының жобаларын әзірлеу және жүзеге асыру;

- ҰМҚ құжаттары бойынша ақпараттық желіні және мәліметтер банкін құру;

- ҰМҚ құжаттарын басып шығару және оларды пайдалану;

- архив жүргізу және құжаттану саласында ғылыми-зерттеу және ғылыми-әдістемелік әрекетті дамыту қарастырылды.

Заңнама Қазақстанның архив қызметінің жаңа концепциясын қалыптастырды. Онда заңды түрде Қазақстанның мемлекеттік мекемелер жүйесінде архив қызметінің орны мен ролі рәсімделді. Заңда архив саласында пайдаланылатын негізгі түсініктермен байланысты сұрақтар кешені көрініс тапты. Қазақстан халықтарының тарихи-мәдени мұрасының бөлігі ретінде ұлттық игілігі ретінде қарастырылған Ұлттық архив қоры түсінігі алғаш рет енгізіледі. Заңға сәйкес Ұлттық архив қоры - бұл қалыптастыру негізі мемлекеттік және жеке меншік архивтер болатын бірыңғай және бүтін жүйе (физикалық және заңды күштердің және олардың бірлестіктерінің). Пайда болған, сақтау орнына тәуелсіз онымен бірдей шамада құқықтық қорғау кепілдендіріледі.

Осылайша, Ұлттық архив қорының құрамына меншік түріне тәуелсіз қоғам үшін құндылық танытатын барлық құжаттар қосылған. Еліміздің архив қоры оның халықтарының материалды және рухани өмірін көрсететін тарихи, ғылыми, әлеуметтік, экономикалық, саяси және мәдени маңызға ие және Қазақстан халықтарының тарихи-мәдени мұрасының ажырамас бөлігі болып табылатын құжаттар жинағы ретінде анықталған.

Қабылданған құжатта қоғам мен мемлекеттік ақпаратқа қажеттіліктерін қанағаттандыруда, архив көздерін пайдалануға біздің еліміздің азаматтарының құқықтары мен заңды қызығушылықтарын жүзеге асыруда Ұлттық архив қорының ролі ерекше көрсетіледі.

Заңда архивтің барлық түрлері үшін жалпы қабылданған құжаттарды орталықтандырылған мемлекеттік тіркеу, сақтау, сақталуын қамтамасыз ету бойынша міндеттер көрініс тапты.

Бүгінгі күні қоғам мен мемлекеттің өмірінде ақпараттың шынайы ролі талассыз өсіп келеді. Архивтер құжаттары белсенді және көлемді түрде пайдаланылатын ақпараттық жүйенің бөлігіне айналып келеді. Архивтік құжаттардағы ақпаратты заң мемлекеттік интеллектуалды меншігі ретінде қарастырады. Архив құжаттамасының пайдаланушыларының құқықтары мен қызығушылықтарын кепілдендіре отырып, нормативтік актте әлемдік тәжірибеде ұсталынатын ақпараттық қауіпсіздік те реттелінеді. Ең алдымен ұлттық қауіпсіздікке, жеке өмір құпиясына зардап тигізуі мүмкін ақпарат туралы айтылады.

Осы заңнамалық акт елдік тарихи мұрасын сақтауда жағымды роль атқарғанымен, бүгінгі таңда құқықтық архив ортасының кемшіліктері анық. Ақпарат саласындағы заңды күші бар көптеген нормативтер архив саласының қызығушылықтарын ескермейді, бұл архивтер мен 
мекемелерді арасындағы өзара қарым-қатынастың қиындығын тудырады. Осылайша, мысалы, еліміздің 1996 жылдың 10 маусымдағы «Авторлық құқық және аралас құқықтар туралы», 1999 жылғы 23 шілдедегі «Бұқаралық ақпарат құралдары туралы» заңдарында аудиовизуалды құжаттардың сақталу, іріктелу және мемлекеттік архивтерге сақтауға берілу сұрақтары қарастырылмайды

[http://adilet.zan.kz/rus/docs/Z960000006; https://online.zakon.kz/document/?doc_id=1005798]. Аудиовизуалды құжаттарды жасайтын көптеген мекемелердің тарихи маңызға ие өткенді шолу кешендерін мемлекеттік архивтерге бергісі келмеуі және сақтау мен пайдаланудың режимдік жағдайын қалыптастыруы қазіргі таңда анық жағдай болып табылады.

Біздің еліміздің архив заңнамасы архивтерде сақталатын ақпаратты алуға әр азаматтың құқығын кеңінен декларациялайды. Ол жалпы ақпаратты алу, құпия ақпаратты қорғау және ақпаратқа тең қолжетімділік құқығы сияқты маңызды қағидалармен құрастырылатын мемлекеттегі ақпаратқа қолжетімділіктің жалпы саясатымен анықталады. Архив құжаттарына қолжетімділік мәселесі өзекті болып қалады.

80-ші жылдардың екінші жартысында архивтерге құпияларға қоғамдық қызығушылықтың белсенді болуының әсерінен біздің тарихымыздың жеке жағдайларын «жергілікті құпиясын ашу» және олардан «мемлекеттік құпия» бүркеуін алу жүргізіледі. Архивтердегі құпиясын ашуға жатқызылатын құжаттар санатына саяси күреспен; партия ішінде индустрияландыру, ұжымдастыру, мәдениетті дамыту жолдары туралы пікірталастарға; мүлікті тәркілеуге; ашаршылықпен; партия саясатының бүлінуінен туындаған қарулы қақтығыстармен; 1930-1950-шы жылдардағы жаппай репрессиялармен; арнайы жер аударылғандармен; тың және тыңайған жерлерді меңгеру салдарымен байланысты ақпараттар жатқызылды.

Архив ақпаратын пайдаланудың маңызды көріністерінің бірі оның қолжетімділігі, ашықтылығымен бірге ақпараттық қауіпсіздікті сақтау болып табылады. Еліміздің архив заңнамасында архив ақпаратына қолжетімділік құқығының кең декларациясымен бірге ресми құжаттардың белгілі бір санатын пайдалануда шектеулер де орнатылады. Қорғаныс қабілетіне, ұлттық қауіпсіздікке, еліміздің экономикалық және саяси қызығушылықтарына қатысты ақпарат мемлекеттік құпия санатына жатқызылған. Осындай ақпарат иегерлері оларды белгілі бір мерзімге құпияландыруға құқылы.

Халықаралық архивтерге Кеңесінің (ХМК) ұсыныстары біздің еліміздің архив заңнамасына белгілі роль атқарды және 30 жылмен есептелетін қолжетімділік мерзімін қысқартуды енгізуге септігін тигізді.

\section{Қорытынды}

Архивтер мемлекеттік институттар бөлігі ретінде құрылған саяси жүйе нормаларына сәйкес қызмет етті. Осы себепті архив жұмысының идеологияландырылған сегменті архив көздерін пайдалану болды. Кеңес билігімен декларацияланған архивтердің ашықтылығына қарамастан, қоғам көптеген онжылдықтарға архив ақпаратының айтарлықтай көп бөлігіне қолжетімділік құқығынан айырылады.

Идеологиялық көрсеткіштер бойынша архив ақпаратын пайдалану, тарихи тақырыптар бойынша жүзеге асырылатын жобалардың тапсырыс сипаты, құжаттарды ресми бекітілген сызба бойынша жариялау ұлттық тарихи ғылымның пайда болу көзі мен ақпараттық базасының тарылуына алып келді.

Құжаттамалық тарихты сақтайтын мекемелер болған тарих аралығында архив ақпараттың архивіне қарым-қатынас әр түрлі болды. Көбінесе ол мемлекеттік нақты даму сатысында архивтерге қандай роль берілгендігіне байланысты болды. Осылайша, кеңестік билік тарихи өткен уақыттың сақталуы туралы ойлаудан басқа, оны саяси және идеологиялық мақсаттарда белсенді түрде пайдалан бастайды. Архивтік құжаттар кеңес биілігінің қолында бұқараның санасына әсер ететін қуатты құралға айналады және бірнеше ондаған жылдар бойы архив құжаттарының саяси және идеологиялық ролін кеңінен пайдаланады. Архивтер негізгі міндеті бұқара санасына сол уақыт сәтінде талап етілетін саяси және идеологиялық нұсқауды енгізуге келтірігне құжатты көздерін пайдаланудың әр түрлі тәсілдері мен әдістері меңгеріледі.

Бүгінгі таңда Қазақстанның архивтері оның үлкен ақпараттық әлеуетімен еліміздің бірыңғай ақпараттық кеңістігіне кіруге ұмтылады. Бұл ақпараттық ресурстарды қалыптастырумен және пайдаланумен ғана емес, сонымен бірге ақпаратқа қолжетімділіктің құқықтық, интеллектуалды, этикалық, физикалық және басқа көріністерін сақтаумен және оны қорғаумен байланыстырылады. 
«Архивтер - 2025» мемлекеттік бағдарламасында архивті ақпараттық саясаттың басымдылықтары анықталған. Олар архивтердің ақпараттық ашықтылық қағидаларын бекітеді. Бағдарлама ережелері негізгі міндет ретінде келесілерді ұсынады: ақпараттық қызмет нарығын бақылау негізінде архив ақпаратын пайдалану; бұрын қолжетімсіз болған архив ақпаратының толық құпиясын ашу; қоғамды архивтік құжаттар туралы Ғаламторда web-парақшалар арқылы ақпараттандыру; архив қызметінде электронды технологияларды пайдалану және т.б. Бұл құжаттың орталық идеясы - архивтердің заманауи көрінісін еліміздің бірыңғай ақпараттық кеңістігінің ажырамас бөлігі ретінде қалыптастыру.

Осы концепцияны ұстана отырып, архивтер өзінің функцияоналды міндеттері ретінде өткенді шолу көздерін кеңінен пайдалану үшін ақпараттық және техникалық инфрақұрылымды құрастыру деп есептейді.

Соңғы онжылдықта ақпараттық ортадағы архивтердің нақты ролі өлшемсіз өсіп келеді. Бүгінгі күні біз архивтерді ақпараттық процестерден тыс елестете алмаймыз, олар бірыңғай ақпараттық кеңістіктің ажырамас құрамдас бөлігіне айналуда. Архивтердің жалпы ақпараттық ортаға «қосылуы» көптеген мәслелерді ашып көрсетті және ең алдымен оның құқықтық көріністерін, сапалы ақпараттық-іздеу құралдарын, физикалық қолжетімділік және т.б.

Демократиялық құндылықтарды ұстанатын кез келген қоғамда ақпаратты, соның ішінде архивтік ақпаратты пайдалану құқықтық шеңберде реттелінеді. Біздің көзқарасымыз бойынша, архив заңнамасының негіздері мемлекеттік архивтерге ұйымдастырушылық-құқықтық түріне тәуелсіз барлық құрылымдардың тарихи маңызды өткенді шолатын құжаттамалық қорларының жағдайын бақылау мүмкіндігін беру бағытында жетілдірілуі керек. Үкіметтің осындай әрекеттері дұрыс ақпарат көзінің базасы қалыптастырылатын ұлттық архивке ведомстволық архивтердің жеткілікті жоғары деңгейде біріктірілуін қамтамасыз ете алатын еді.

Архивтер, жалпы архив ісі деңгейінде жинақталған тәжірибені зерттеу, талдау және жалпыландыру заманауи уақыттың өзекті міндеті болып қалады.

\section{Пайдальилван әдебиеттер тізімі:}

1. Архивное строительство в Казахской ССР (1918-1980 гг.). Сборник законодательных и руководящих документов. Алма-Ата, 1980. - 233 с.

2. Максаков В. В. История и организаџия архивного дела в СССР (1917-1945). М.. 1969, с. 57, $121-122$

3. Grimsted P.K. Lenin's Archival Decree of 1918:The Bolshevik Legacy for SovietArchival Theory and Practice American Archivist/Vol. 45, No. 4/Fall 1982, pp.429-443.

4. Grimsted P.K Archives in Soviet Union: Their Organization and the Problem of Access // American Archivist. 1971. Vol. 34. No. 1 (Jan.). P. 27-41, Grimsted P.K. Regional Archival Development in the USSR: Soviet Standards and National Documentary Legacies //American Archivist. 1973. Vol. 36. No. 1 (Jan.). P. 43-46.

5. Grimsted P.K. Glasnost' in the Archives? Recent Developments on the Soviet Archival Scene // American Archivist. 1989. Vol. 52. No. 2 (Spring). P. 214-236, Grimsted P.K. Perestroika in the Archives,?: Further Efforts at Soviet Archival Reform //American Archivist. 1991. Vol. 54. No. 1 (Winter). P. 70-95

6. Grimsted P.K. Beyond Perestroika: Soviet-Area Archives After the August Coup // American Archivist. 1992. Vol. 55. No. 1 (Winter). P. 94-124

7. Архивное строительство..., 1980, с. 26-27

8. Сборник руководящих материалов по архивному делу (1917-июнь 1941 г2.). М., 1961. С. $109-111$.

9. Советские архивы, 1978, № 3, с.21.

10.Архивное строительство..., 1980, с. 208

11.Архивное строительство..., 1980, с. 164-166

12.ЦГА РК. Ф. 544. On. 1. Д. 5, л. 2-3.

13.ЦГА КазССР, ф.544, on.1, д.1836, л.43.

14.http://archives.ru/documents/methodics/review-archival-delo-sng.shtml.

15.https://zakon.uchet.kz/rus/docs/Z980000326_

16.http://adilet.zan.kz/rus/docs/Z960000006;

17.https://online.zakon.kz/document/?doc_id $=1005798$ 


\section{References:}

19. 1. archival construction in the Kazakh SSR (1918-1980).). Collection of legislative and guiding documents. - Alma-Ata, 1980. - 233 P.

20. 2. Maksakov V. V. history and organization of archival affairs in the USSR (1917-1945). MOSCOW, 1969. - PP. 57, 121-122

21. 3. Grimsted P.K. Lenin's Archival Decree of 1918:The Bolshevik Legacy for SovietArchival Theory and Practice American Archivist/Vol. 45, No. 4 / Fall 1982, pp.429-443.

22. 4. Grimsted R. K. Archives in Soviet Union: Their Organization and the Problem of Access // American Archivist. 1971. Vol. 34. No. 1 (Jan.). P. 27-41, Grimsted P.K. Regional Archival Development in the USSR: Soviet Standards and National Documentary Legacies //American Archivist. 1973. Vol. 36. No. 1 (Jan.). P. 43-46.

23. 5. Grimsted P.K. Glasnost' in the Archives? Recent Developments on the Soviet Archival Scene // American Archivist. 1989. Vol. 52. No. 2 (Spring). P. 214-236, Grimsted P.K. Perestroika in the Archives? Further Efforts at Soviet Archival Reform //American Archivist. 1991. Vol. 54. No. 1 (Winter). - P. 70-95

24. 6. Grimsted P.K. Beyond Perestroika: Soviet-Area Archives After the August Coup // American Archivist. 1992. Vol. 55. No. 1 (Winter). - P. 94-124.

25. 7. archival construction..., 1980, pp. 26-27.

26. 8.collection of archival materials (1917-June 1941).). MOSCOW, 1961. - PP. 109-111.

27. 9. Soviet archives, 1978, No. 3, p. 21.

28. 10. archival construction..., 1980, p. 208.

29. 11. archival construction..., 1980, pp. 164-166.

30. 12. TSGA RK. F. 544.Op. 1. D. 5, L. 2-3.

31. 13. TSGA Kazssr, F. 544, op.1, D. 1836, L. 43.

32. 14. http://archives.ru/documents/methodics/review-archival-delo-sng.shtml.

33. 15. https://zakon.uchet.kz/rus/docs/Z980000326_

34. 16. http://adilet.zan.kz/rus/docs/Z960000006;

35. 17. https://online.zakon.kz/document/?doc_id $=1005798$ 